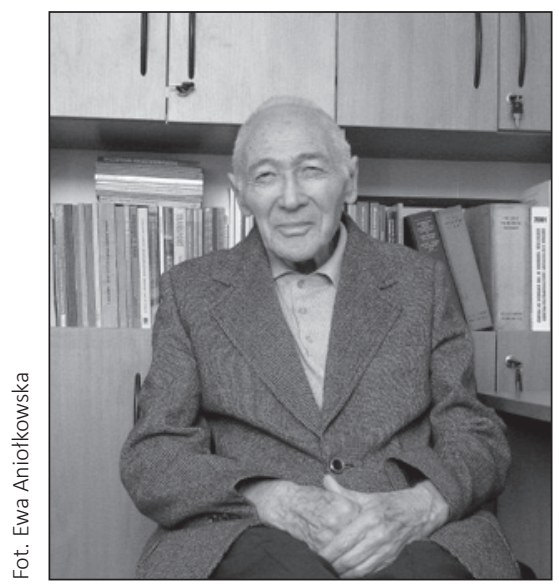

Profesor Izasław Frenkel (1929-2020)

\title{
Wspomnienie o Profesorze Izasławie Frenklu
}

\author{
In Memoriam: Professor Izasław Frenkel
}

$\mathrm{W}$ połowie lat 70. ubiegłego wieku pierwszy raz zetknąłem się z nazwiskiem Izasława Frenkla. A było tak. Pracowałem wtedy w Instytucie Ekonomiki Rolnej. Analizowałem dane Narodowego Spisu Powszechnego z 1970 r. i nie mogłem rozgryźć, na podstawie przyjętych przez ówczesne Biuro Spisów GUS definicji, tego, jak klasyfikowane są dane przypadki. Postanowiłem więc sięgnąć do źródła, zwłaszcza że z wcześniejszych kontaktów wiedziałem, iż pracownicy Biura Spisów bardzo życzliwie i cierpliwie wyjaśniają użytkownikom danych wszelkie zawiłości materiału. Wizyta trwała dość długo, autorki definicji spisowych nie mogły bowiem odtworzyć wszystkich przyjętych ustaleń metodycznych. Również lektura instrukcji dla rachmistrza spisowego i instrukcji kodowania cech z kwestionariusza nie rozwiały wątpliwości. Po dłuższych analizach różnych dokumentów padła propozycja: „Trzeba zadzwonić do doktora Frenkla, on na pewno będzie wiedział”. I pomysł okazał się skuteczny, dr Izasław Frenkel przez telefon w kilka minut wyjaśnił sprawę interpretacji przyjętych kategorii spisowych. 
Po tym pierwszym doświadczeniu zwracałem uwagę na wszystkie publikacje dr. Frenkla, jakie wpadały mi w ręce. Nabrałem przekonania, że problematyka, którą się zajmował, jest bardzo bliska temu, co mnie wówczas interesowało. Człowieka jednak nie znałem, nie wiedziałem jak wygląda, jak mówi...

Poznałem go osobiście w dość specyficznych okolicznościach - w trakcie obrony mojego doktoratu. Już po autoreferacie, wypowiedziach recenzentów i udzieleniu odpowiedzi, których oczekiwali, zacząłem odpowiadać na pytania z sali. Wśród nich wyróżniały się te zadawane przez niewielkiego mężczyznę, który, jak czułem, przeczytał pracę i dostrzegł w niej mocne, ale i słabsze strony. Co więcej, po każdej udzielonej przeze mnie odpowiedzi drążył temat. Trwało to jakiś czas, aż w końcu przestał, oświadczając, że jest usatysfakcjonowany moimi odpowiedziami, ja jednak czułem, iż sprawa była bardziej złożona. Kiedy wyproszono mnie i tzw. publiczność z sali na czas obrad Rady Naukowej, podszedł do mnie, przedstawił się i powiedział:

Przepraszam, zagalopowałem się. Wiadomo, że w trakcie obrony doktorant jest zestresowany i nie jest to najlepsza okazja do merytorycznej dyskusji. Chciałbym się kiedyś spotkać i porozmawiać w bardziej sprzyjających okolicznościach. Może z tego wyniknie coś, np. jakaś współpraca, bo zajmuję się podobnymi sprawami.

Okazja do współpracy nadarzyła się szybciej niż przypuszczaliśmy. Kilka miesięcy później pracowałem już w Instytucie Rozwoju Wsi i Rolnictwa PAN, a Sławek (nie lubił oficjalnej tytulatury w sytuacjach tego niewymagających, toteż niemal od razu zaproponował byśmy mówili sobie po imieniu) stał się moim szefem. Szybko zorientowałem się, że praktycznie ze wszystkimi w Instytucie był po imieniu. A zależność służbowa z czasem ulegała ewolucji, najpierw on był moim szefem, potem ja jego, potem znowu on moim... I tak przez prawie 50 lat. Jednakże zależność formalna nie miała większego znaczenia - niezależnie bowiem od tego, kto akurat szefował, uważałem go za swojego mistrza. Mam świadomość, że choć pozornie współpracowaliśmy na zasadach równości, to jednak przede wszystkim ja się od niego uczyłem. Pod wieloma względami imponował mi, zwłaszcza tym, że choć jego prace miały charakter ściśle demograficzny, to zjawiska, o których pisał, widział w szerokim kontekście kulturowym, ekonomicznym, politycznym, a nawet medycznym. Również tym, że za technicznymi pojęciami używanymi w statystyce, takimi jak gospodarstwo domowe, bierność zawodowa, dodatkowe źródła utrzymania i wieloma podobnymi widział nie tylko konwencje terminologiczne służące agregowaniu danych, lecz także rzeczywistość społeczną. Inną cechą Sławka był specyficzny stosunek do liczb. Z jednej strony był on bardzo skrupulatny, każda liczba podawana przez GUS lub pochodząca z badań była przez niego analizowana 
pod kątem tego, jak pozyskano dane i co w rzeczywistości oznacza, z drugiej zaś zdawał sobie sprawę, że stanowi ona tylko przybliżony obraz fragmentu rzeczywistości, której dotyczy.

Współpraca ta była bardzo intensywna, razem pracowaliśmy w różnych „problemach węzłowych", przy ekspertyzach, referatach konferencyjnych, a w późniejszym okresie też grantach. Przeważnie spotykaliśmy się po południu, u niego lub u mnie $\mathrm{w}$ domu i praca, przerywana kolacją i dla rozprężenia rozmowami na inne tematy, trwała do ostatniego autobusu, a później, kiedy dysponował już samochodem - do północy. W konsekwencji Sławek miał już stałe „własne” miejsce przy stole w jadalni w moim domu, a ja w jego. Nasze żony zdążyły dobrze się poznać, Sławek był zaprzyjaźniony z moją córką, a ja z jego synem. Wiele powstałych w wyniku takiej współpracy tekstów publikowaliśmy pod dwoma nazwiskami. Doszło do tego, że kiedyś na adres Instytutu przyszło zaproszenie na konferencję zaadresowane: „prof. Frenkel-Rosner”.

Po tym zdarzeniu stwierdziliśmy, że powinniśmy więcej pracować oddzielnie i publikować pod jednym - swoim nazwiskiem.

Postanowienie było twarde, okazało się jednak dość krótkotrwałe. Tak się zdarzyło, że do Polski przyjechał z żoną na wakacje zaprzyjaźniony ze mną profesor Paolo Santacroce z Uniwersytetu IUAV w Wenecji. Interesował się on, nad czym pracujemy i opowiadał o tym, jakie możliwości daje komputerowa obróbka danych i przedstawianie ich w postaci graficznej, np. map. Zaraził nas ideą zajęcia się tą, wówczas bardzo świeżą, techniką pracy. Warto dodać, że był to okres, kiedy w Instytucie były zaledwie trzy komputery osobiste, z czego jeden, nowocześniejszy, z kolorowym monitorem i procesorem 286. Drukarka igłowa wydawała się szczytem wyrafinowania technicznego. Był to więc czas, w którym dostęp do jakiegokolwiek komputera mniejszego niż „Odra” był rzadkością. Jednak największa walizka przywieziona przez Paola okazała się laptopem, mogliśmy więc nie tylko marzyć, ale też przetestować, co taki sprzęt może zrobić.

Takie były początki projektu, w którym z powrotem pracowałem ze Sławkiem, ale tym razem w większym towarzystwie, bo z udziałem Paola, jego żony Annalisy Conte, oraz Bożeny Andrychowicz, wówczas asystentki pracującej w IRWiR PAN. Paolo, wykorzystując możliwości sprzętu Uniwersytetu IUAV w Wenecji, opracował pierwszą $\mathrm{w}$ historii komputerową mapę konturową Polski. Wykonał też, w oparciu o przygotowane przez nas przykładowe dane, pierwsze wydruki kolorowe. Okazały się tak obiecujące, że biuro warszawskie Banku Światowego sprowadziło do Polski jedną z pierwszych drukarek kolorowych i wypożyczyło ją na nasze potrzeby do IRWiR PAN. Skutkiem tych działań było powstanie Atlasu demograficznego i społeczno-zawodowego obszarów wiejskich w Polsce. Publikacja Atlasu... spotkała się z bardzo pozytywnym przyjęciem recenzentów. Paolo został 
odznaczony Medalem Kopernika przez Prezesa PAN, a dla Sławka i dla mnie projekt ten oznaczał powrót do bliższej współpracy, z tym że już na innych zasadach, respektujących fakt, iż nie jesteśmy jedną osobą.

Wspólnota zainteresowań powodowała również to, że kilkakrotnie wyjeżdżaliśmy razem za granicę w ramach tzw. wymiany bezdewizowej. Byliśmy razem w Chinach, gdzie interesowały nas migracje wieś-miasto, bardzo wówczas intensywne, choć nie do końca legalne. W Bułgarii ciekawily nas problemy zapewnienia siły roboczej w bardzo rozległych przestrzennie, ale scentralizowanych organizacyjnie Kompleksach Rolno-Przemysłowych. W Rosji, w Nowosybirsku, zapoznaliśmy się u źródła z tzw. eksperymentem nowosybirskim dotyczącym prób restrukturyzacji kołchozów. Niezwykle ciekawe były spotkania z prof. Tatianą Zasławską, która opowiadała o problemach wsi radzieckiej epoki głasnosti, a sama była niezwykle zainteresowana reformami w Polsce $\mathrm{z}$ początku lat 80. XX w.

Każdy z tych wyjazdów zapowiadał się interesująco nie tylko ze względów merytorycznych, lecz także turystycznych. Jednak dociekliwość Sławka powodowała, że rozmowy w instytutach, do których jechaliśmy, trwały często do wieczora. Stało się też normą, że poza zaplanowanymi spotkaniami odbywaliśmy też wiele dodatkowych - organizowanych na miejscu, będących konsekwencją dociekliwości Sławka, której często nie doceniali rozmówcy na spotkaniach umówionych z góry.

Wieczorami w hotelach mieliśmy czas na skomentowanie spotkań oraz inne rozmowy. W takich okolicznościach dowiedziałem się szczegółów życia Sławka z okresu wojny i pobytu w ZSRR. Opowiadał też o okresie studiów w Moskwie, o pobycie w Brygadach Międzynarodowych w Jugosławii, o okresie pracy w zespole prof. Michała Kaleckiego, o 1968 roku. Muszę przyznać, że życiorys miał bardzo bogaty - różnych, często dramatycznych wydarzeń starczyłoby dla kilku osób. Nie czuję się jednak upoważniony do tego, aby o nich pisać.

W czasie podróży zagranicznych zdarzały się też sytuacje komiczne. Do jednej $\mathrm{z}$ nich doszło w trakcie przesiadki w Moskwie, podczas powrotu z Nowosybirska. Na lotnisku okazało się, że musimy wypełnić jakieś, zresztą proste, deklaracje. Sławek świetnie posługiwał się językiem rosyjskim, więc usiadł na parapecie poczekalni i wypełnił obie. Wtedy już bez przeszkód mogliśmy przejść przez granicę. Okazało się jednak, że na parapecie Sławek zostawił czapkę. Próbował po nią wrócić, ale lotniskowy pogranicznik uświadomił go w sposób nieznoszący sprzeciwu, że przekroczył granicę i ponowne jej przejście nie jest możliwe. Próba nakłonienia go, aby przyniósł czapkę też nie przyniosła rezultatu - powiedział, że jest to własność cudzoziemca i nie ma prawa jej dotykać. Sprawa oparła się o dowódcę zmiany, który po konsultacji telefonicznej z wyższymi władzami powiedział, że Sławek może podejść do parapetu i zabrać czapkę, ale w towarzystwie dwóch eskortujących go żołnierzy z karabinami. 
Miałem szczęście, że los zetknął mnie ze Sławkiem Frenklem. Bardzo dużo się od niego nauczyłem, niewątpliwie też wpłynął na mój sposób postrzegania świata. Był wybitną umysłowością, bardzo dociekliwą w sprawach merytorycznych i przepełnioną życzliwością dla ludzi. Pozostawił po sobie wiele bardzo ciekawych publikacji, ale i wspomnienie człowieka mądrego, chętnie niosącego pomoc i lojalnego.

Andrzej Rosner 
